the circulation. Dr. White in his last letter says that localised external pressure by altering the distribution of the blood will cause the blood pressure to be increased and argues from this that the phenomenon is a purely physical one. I do not, however, agree with this statement.

In a normal individual localised external pressure will not cause any rise in the blood pressure, as the vaso-motor centre at once compensates for any alteration in pressure which tends to take place. Thus compression of the abdomen in a healthy person causes little or no alteration in the blood pressure, while the same amount of compression in a patient suffering from shock will result in a considerable rise in the blood pressure. I would suggest to Dr. White that he should carry out a series of experiments to test the value of his assertions. I am sure that he will agree with me that arguments not based upon experiments are of little value in discussions on morbid physiology and I believe that if Dr. White carries out such experiments he will not long hold his present views. Many of the problems in relation to the blood pressure in health and disease which have been touched upon in this discussion give ample scope for further investigation along experimental lines. I do not think that arguments unbacked by experimental proof can be of much value and I trust that Dr. White will aid the cause of morbid physiology by testing his ideas by experimental research. I am, Sirs, yours faithfully.

Cavendish-place, April 17th, 1905. P. LOCKHART MUMmery.

\section{POISONING BY THE WASTE GASES OF THE MOTOR-CAR.}

To the Editors of THE LANCET.

SIRS, - In the course of the last few years the public has been brought in contact with the petrol engine as a result of the latter being adopted for road traction. I have seen no mention in the medical or motor papers, nor I am sure are owners of cars and their mechanics aware of the danger of inhaling the waste gases. That this danger is a serious one the following instance will demonstrate. In a room of about 2000 cubic feet capacity, the doors and windows of which were closed, four men for the space of 20 minutes were engaged in testing an eight horse-power engine, which they allowed to run and to rest for alternate intervals of two minutes and one minute respectively. Before the completion of the trial two of the men went out complaining of "feeling bad" and had nausea; their fellows who persevered with the trial were subsequently sick and all four complained of violent headache, throbbing of the temples, and of a feeling as though their heads would burst. All were able to resume work the following morning, but one came to see me some two or three days later with recent and marked anæmia, and although previously in perfect health developed in the course of a few days a large carbuncle. The symptoms I have narrated seem to point to poisoning by carbon monoxide and should act as a warning to others.

I am, Sirs, yours faithfully,

Wimbledon, S.W., April 17th, 1905. W. B. WINTON,

\section{THE "CURE" OF CANCER.}

\section{To the Editors of THE LANCET.}

SIRS,-Many surgeons will regret to read the somewhat pessimistic article under the above heading published in THE LANCET of April 15th by Mr. Edmund Owen. Looked at with the "cold and unemotional eye" of surgery it is literally true, but most, I think, will agree that Mr. Owen is unduly sensitive when he is unable to satisfy himself of having cured the case he quotes (the nature of which, by the way, he does not state was verified by microscopical examination), notwithstanding that the patient has remained free from recurrence for over a quarter of a century. There is a good deal in medicine and surgery which is incapable of absolute mathematical demonstration and it is obvious on Mr. Owen's argument that no case of cancer could ever be claimed to have been cured by operation, because if the patient lived to 100 years and passed 50 without a recurrence, dying eventually, as Mr. Owen's case seems likely to do, from old age, it could always be argued that if he had lived to 120 he might have had a recurrence. He could not therefore be claimed to have been cured, even though he lived to a ripe old age and died from something else. Such an argument is, no doubt, logically free from flaw but most surgeons will be satisfied that Mr. Owen has obtained a cure and the patient is no doubt satisfied of it herself. Indeed, " wonderfully well and active and in her eighty-fourth year," and free from recurrence after a quarter of a century, I venture to think that it would be difficult to convince her of the contrary. Mr. Owen says that the most the surgeon can promise his patient is that he will "do his best." Clumsy comfort, indeed, for the unfortunate sufferer from this terrible disease. Moreover, the patient will have taken that much for granted before he ever consulted the surgeon. Everybody admits that the three years' limit is an arbitrary one. Everybody admits that cancer cells or germs can apparently lie dormant for years, can then cause recurrence, belie hopes, and spoil statistics (though it remains to be proved that some of these recurrences are not independent outbreaks of the disease, in which case they will fall into exactly the same category as Mr. Owen's broken thigh bone or abscess of the hand).

But granted all this, are we not, I would ask, in the light of recent results, justified in giving our patient just a little more encouragement than that we shall "do our best"? Surely we are. Surely our attitude to our patients should be one of distinct encouragement, begotten of the vastly improved results of operation in recent years, more especially as this encouragement is our most powerful weapon in the education of the public in the paramount necessity of early recognition and early operation. When the public are educated up to and encouraged to the fact that they can be cured then we shall see fewer of the "too late" cases and our percentages of cures will go up. And if it be conceded that cancer in the first instance is a local disease it must be admitted that every case of cancer, if it could be seen early enough and removed early enough, is curable. What has led to the vastly improved results of operation in recent years? It is the fact that the surgeon now operates with the thoroughness begotten of the hope, the expectation, the determination to eradicate the disease, not in the slipshod fashion of the man of 30 years ago who was convinced of the utter hopelessness of the complaint which he was dealing with. What is required to still better the results? The encouragement in the public that it is possible to cure them. Mr. Owen's simile of the bottle thrown out to sea turning up again after years adrift is apposite so far as it goes. But he omits to record the fact that the bottle frequently does not turn up at all. Moreover, Mr. Owen admits that in certain cases operation can bring lasting relief. What is this but cure? I cannot see the difference. At all events it is a good enough cure for the patient, even though it may not -satisfy the "cold and unemotional" mind of the surgeon.

I am, Sirs, yours faithfully,

ChaRles P. Childe, B.A., F.R.C.S. Eng.,

Southsea, April 20th, 1905 . Assistant Surgeon, Royal Portsmouth Hospital.

\section{PIROPLASMOSIS OR RED-WATER FEVER.}

\section{To the Editors of THE LANCET.}

SIRs,-In examining a number of blood films for nematode infection I have chanced to come across a case of piroplasmosis. The hæmosporidia are to be seen, both intracorpuscular and free, in the blood plasma. Seven years ago the patient spent some two and a half years in America, where I conjecture that some insect, probably a tick, inflicted an infective wound. I should esteem it a great favour to learn through your columns whether this disease has been noticed to have affected man previous to the present time. I am, Sirs, yours faithfully,

Birmingham, April 24th, $1905 . \quad$ J. DENCER WHITTLES.

\section{UNFORTUNATE ADVERTISEMENT}

\section{To the Editors of THE LANCET.}

SIRs,--The columns of the Times to-day contain an article dealing with the work done by St. Bartholomew's Hospital, written in a style which may have its attractions (for some readers) and has for its object the increase of the income of the hospital, but surely it is not necessary to pillory " the stoutish man, black-bearded and with bald crown of shining pallor," and why should the house surgeons and dressers be brought before the public and described as "lithe and alert men with a firmness of mouth, a quiet grip in the eye" (sic), and dubbed "Young Davids, sworn enemies of death and saviours of life." Surely a remon strance from members of the surgical staff would compel 